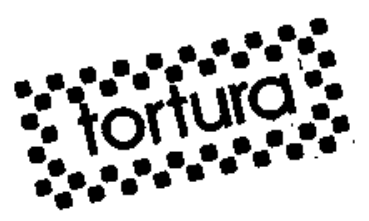

"Como o senhor explica o fenómeno da tortura?"

Dom Paulo Evaristo Arns - Este fenômeno tem voltado a acontecer ao longo da história. Por isso é preciso procurar de fato as suas raízes e as suas causas mais profundas. Algumas destas residem na própria natureza vingativa da pessoa humana. Por exemplo, a pessoa que em sua casa tortura a sua esposa ou o seu marido, os seus filhos, as outras pessoas. Nós sabemos hoje que é um fenômeno mais doentio do que normal, mas ocorre muito.

Agora o fenômeno da tortura política é mais evidente e doloroso quando, por exemplo, um Estado organiza a tortura de maneira a fazer dela um instrumento para uma guerra "intestina" - como eles dizem - ou para acabar com uma subversão. Isso também aconteceu na Antigüidade e se repetiu na era moderna como, por exemplo, no hitlerismo. Temos provas evidentes de que foi implantado no Brasil desde 1966 e durou até o fim da ditadura militar. Nós sabemos que ela veio de um ideologia, ou seja, da Lei de Segurança Nacional. As pessoas achavam que assim poderiam defender a comunidade contra as pessoas subversivas, o que de fato não se deu. Eu mesmo conversando com delegados de polícia e até com o Chefe da Polícia, um Secretário da Segurança Pública na época, perguntei: por que os senhores torturam? Eles sempres respondiam que tinham pressa

\title{
A incidência no país: ontem e agora.
}

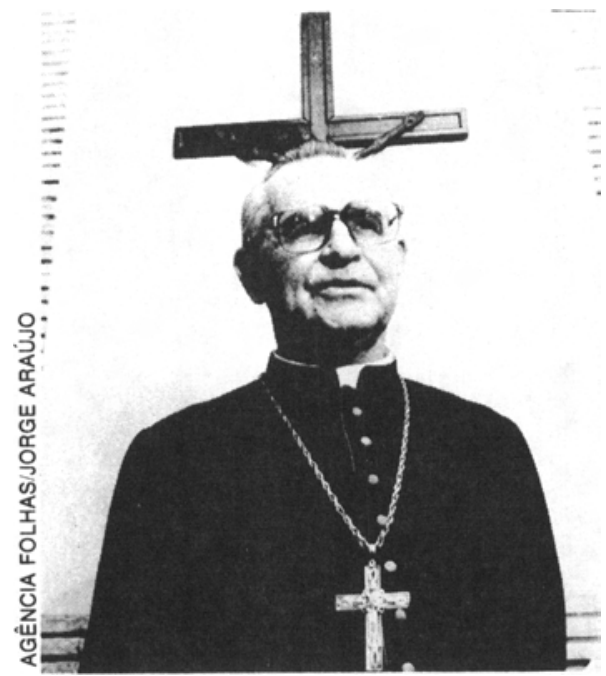

em obter informaçōes e descobrir cúmplices ou, como diziam naquele tempo, descobrir "aparelhos".

De fato, porém, examinando todo o arsenal de informaçōes que colhemos através de nossas pesquisas nos processos e também ouvindo pessoas torturadas, eu posso garantir (e todos os psicólogos podem verificá-lo) que a tortura nãọ é nenhuma fonte boa de informaçōes porque ela mesma leva a confundir dados e pessoas. Em segundo lugar, ela não é justificável juridicamente e nem moralmente, sob nenhum pretexto.

Ao assinar o projeto das Naçōes Unidas contra a tortura, o Brasil aceita o compromisso de jamais permitir que, em nome de qualquer mal que possa surgir ou de qualquer obstáculo que possa opor-se às vontades dos governantes, a tortura se repita entre nós.
No entanto, é um fenômeno que merece um estudo mais aprofundado. Eu gostaria muito que as pessoas que me lêem agora, consultassem o repertório que nós possuímos na Cúria Metropolitana e que forneceram dados para o projetớBrasil Urgente".São seis mil e novecentas e tantas páginas. O material se encontra à disposição de todos na Cúria Metropolitana e no Arquivo Metropolitano, em São Paulo. Seria muito interessante verificar ali os dados objetivos: como ć que surge a tortura e quais são as raízes que infelizmente brotam de novo, tanto no coração humano quanto no coração da sociedade dominadora.

"Qual é a experiência do senhor com pessoas que estiveram envolvidas com tortura no Brasil?"

Dom Paulo. E.Arns-A experiência é dupla. A primeira é a experiência com torturadores. $O$ general Golbery do Couto e Silva, que foi durante muito tempo o Chefe da Casa Civil do Governo Geisel e depois do Figueiredo, me disse que o torturador na primeira vez se apavora; na segunda, ainda sente remorsos; e depois de meia dúzia de vezes, sènte necessidade de torturar, tornando-se um verdadeiro monstro e, quando não pode torturar na cadeia, chega a toturar em casa até os próprios filhos e a esposa.

Eu também tive muitos contatos com torturadores e posso dizer que quase todos apresentam anomalias extraordinárias. Alguns deles me chegaram a confessar que a esposa estava 
em tratamento por causa das torturas - até inconscientes - que eles inflingiam em casa. Um outro caso: um filho matar alguém porque já não sentia mais o mesmo pai que se tornou brutal. Assim, caso por caso, a tortura sempre deixa crescer na pessoa humana o lado animal abafando - lado humanitário, espiritual, moral, ético. Então, a tortura gera monstros.

A segunda experiência é com torturados. Eu tive mais experiências com torturados do que com torturadores. Foram certamente centenas, se não chegaram a milhares. Alguns puderam desabafar mais pessoalmente e outros deram por escrito toda a experiência para passarem por uma catarse e, portanto, purificarem a própria vida.

Com todos os torturados eu pude verificar uns fenômenos que até parecem contraditórios. Por exemplo, quase todos eles eram suaves e não queriam vingança. Coisa bem curiosa, mas muitos deles tinham sido despersonalizados. Quer dizer que a tortura vai tirando uma por uma as fatias da pessoa humana a ponto de ela empobrecer tanto e não ser mais como era antes: afável, bondosa, cheia de iniciativas, cheia de amizades. A tortura forjou uma outra pessoa e empurrou para dentro dela uma outra forma diversa da dela.

Eu me lembro de um caso: um professor veio me apresentar a sua filha que, aos 22 anos, foi torturada durante 10 dias sem culpa nenhuma, sem nenhuma atividade política. Depois, quando voltou para casa, o pai nào a reconheceu mais em todas as reações dela. E mesmo quando a trouxe a minha presença ela ficava sentada, sem reação, e via o pai todo nervoso falando que "se a filha reconhecer o torturador, eu mato essa pessoa, porque levei 22 anos para formar uma filha e agora, veja, não tem mais nada do que era a minha filha. Não é mais ela; só fisicamente é a mesma". Essa moça se tornou totalmente alheada a tudo que se passa.

Me parece que a experiência com torturado é a experiência mais dolorosa que pode existir na vida humana. Você pode encontrar-se com alguém

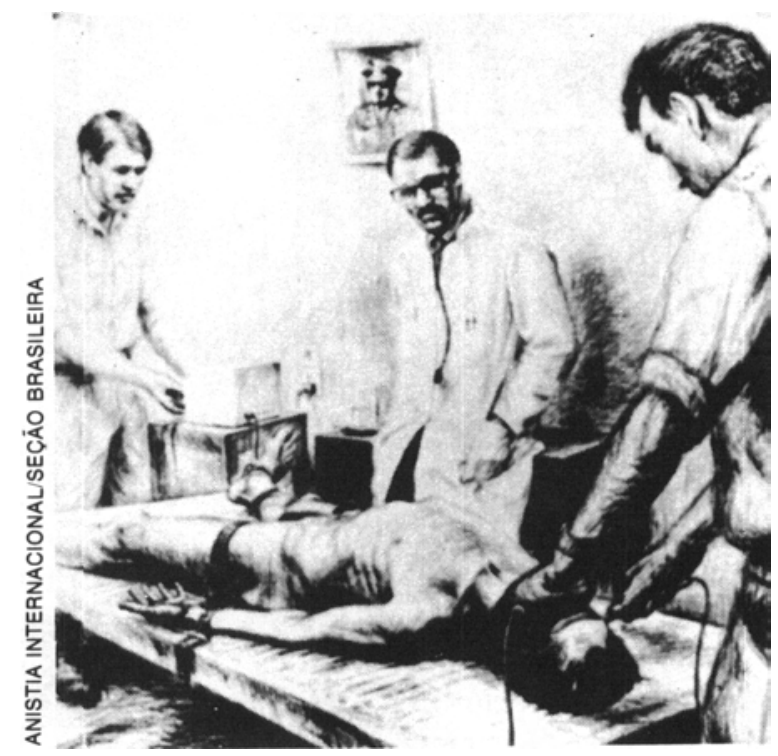

que seja leproso, aidético, mas, com torturado que ficou com as marcas mesmas da tortura, você dificilmente se entende e você deveria exclamar o que Pilatos exclamou diante de Cristo: ecce homo, quer dizer, a que é que reduziram a pessoa humana.

"O que fazer para que a tortura não volte a ser praticada na nossa sociedade, e para que não se crie uma amnésia sobre estes fatos recentes na sociedade brasileira?"

Dom Paulo E. Arns - Eu acho que esta pergunta é a mais importante. Foi para isso que nós organizamos um grupo de 25 a 35 especialistas que reuniram todos os processos de torturasocorridas no Brasil e que foram levados a juízo, quer dizer, foram depoimentos prestados diante de juízes militares. De 1979 a 85, nós pesquisamos esse material e o publicamos sob a forma de livro (Brasil: Nunca Mais, Editora Vozes, 1986) para que não se apague a memória da tortura no Brasil.

De fato, porém, o povo os esquece muito depressa. Eu acho que a educacaao deve começar desde pequeno. Jamais a mãe deve bater no filho. Jamais o pai deve externar o seu nervosismo em cima do filho, ou gritando com a esposa. Essas coisas não parecem nada, desde pequenos, porque são feitos por pessoas grandes. Elas entram no coração da pessoa e um dia ela se vinga. Dizem que, por exemplo, um pastor alemão, você não pode bater nele porque um dia ele vai avançar em cima de você e vai se vingar. Portanto, nunca faça isso. Muito mais se deve evitar no caso da pessoa humana. Jamais se deve levar uma crueldade para dentro do lar, da escola, da sociedade, em qualquer lugar.

Um segundo ponto que me parece importante é formar sempre grupos de defesa contra a tortura. Por exemplo, nesse momento, em São Paulo, estão sendo torturadas pessoas. $\mathrm{Na}$ hora em que lhe dou a entrevista (dia 29 de julho de 87, cerca de 17 horas), em algum ambiente policial, alguém está sendo batido, torturado para poder fazer alguma coisa. Eu estou recebendo, nesse momento, um bilhetinho dizendo que há uma rebelião na Casa de Detenção, com 40 reféns. Você vai ver: depois que isso passar, vão colocar sob tortura algumas pessoas para saber quem $\varepsilon$ que fez, o que fez, como fez. Nós sempre devíamos protestar. Cada vez que isso acontece nós devíamos estar ao lado das pessoas torturadas e fazer o que nós pudermos fazer. Vamos, então, ver a nossa obrigação, levar a nossa mensagem aos outros e procurar criar um clima de compreensão e de aceitação dos outros como eles são.

Endereço da Cúria Metropolitana: Avenida Higienópolis, 890, tel. (011)826.0133, CEP 01238, São Paulo. 